\title{
Anti-Ula as the Cause of Severe Hemolytic Disease of the Fetus and Newborn: A Case Report
}

\author{
Riina Jernman ${ }^{1 *}$, Katri Haimila ${ }^{2}$, Anu Korhonen², Inna Sareneva ${ }^{2}$, Kati Sulin², Jukka Uotila ${ }^{3}$, Malla \\ Kuosmanen ${ }^{2}$ and Susanna Sainio ${ }^{2}$
}

${ }^{1}$ Department of Obstetrics and Gynecology, University of Helsinki and Helsinki University Hospital, Finland

${ }^{2}$ Finnish Red Cross Blood Service, Finland

${ }^{3}$ Department of Obstetrics and Gynecology, Tampere University Hospital, Finland

*Corresponding author: Riina Jernman, Department of Obstetrics and Gynecology, University of Helsinki and Helsinki University Hospital, P.O. Box 140, 00029 HUS, Helsinki, Finland, Tel: +358505351025; E-mail: riina.jernman@hus.fi

Received date: 23 May, 2016; Accepted date: 27 June, 2016; Published date: 29 June, 2016

Citation: Jernman R, Haimila K, Korhonen A, et al. Anti-Ula as the Cause of Severe Hemolytic Disease of the Fetus and Newborn: A Case Report, Gynecol Obstet Case Rep. 2016, 2:2.

\section{Abstract}

Background: Ula, part of the Kell blood group system, is a low-frequency antigen found predominantly in the Finnish population. Anti-Ula is a rare antibody to cause hemolytic disease of the fetus and newborn (HDFN).

Methods and Findings: We report one woman with two pregnancies in which anti-Ula caused severe HDFN requiring intrauterine (IU) transfusions. In the first affected pregnancy, two IU transfusions were performed, but the cause of fetal anemia was unknown at the time and an immune-based mechanism was not suspected. In the following pregnancy, anti-Ula with a titer of 1-2 was identified, and as the fetus was anemic, six IU transfusions were performed. The detection of anti-Ula is difficult, because it is not usually included in the antibody screening cells.

Conclusions: The possibility of a rare antibody as the cause of severe HDFN should be kept in mind in cases in which the antibody screening has been negative, and further antibody detection studies should be performed as part of fetal anemia investigations. If anti-Ula is identified in a pregnant woman, close ultrasound monitoring of the fetus is important because HDFN may develop even when the antibody titers are low.

Keywords: Anti-Ula; HDFN; Alloimmunization; Intrauterine transfusion

\section{Abbrevations:}

DAT: Direct Antiglobulin Test; HDFN: Hemolytic Disease of the Fetus and Newborn; IU: Intrauterine; MCA: Middle Cerebral Artery; MoM: Multiples of Median; PSV: Peak Systolic Velocity; RBC: Red Blood Cell

\section{Introduction}

The Ula antigen was first discovered in 1968 by Furuhjelm et al. in a Finnish patient after whom the antigen was named [1]. In 1969, Ula was shown to belong to the Kell blood group system, named KEL10 [2]. Ula is a rare antigen, with an occurrence of $<0.01 \%$ in the general population and $0.46 \%$ in the Japanese population, while in Finland the occurrence is $2.6 \%$, and even higher in some regions. Thus, Ula is often considered a predominantly Finnish characteristic. The molecular basis associated with the Ula antigen is: Amino acid Val494, Nucleotide T at bp 1481 in exon 13 (Ul(a-): A at bp 1481 and Glu494) [3,4]. Anti-Ula is regularly seen in Finnish patients after red blood cell (RBC) transfusions; anti-Ula is detected in serological cross-matching preceding the transfusion, or, if type and screen is used, when an additional screening cell positive for rare antigens such as Ula is applied.

Anti-Ula is generally not considered to be of importance as the cause of severe hemolytic disease of the fetus and newborn (HDFN) and therefore it is not included in the screening cells used in antenatal antibody screening. Only one case of HDFN caused by anti-Ula has been reported, but the severity of the disease was not described [5]. In the study by Furuhjelm et al. no anti-Ula was detected in the serum of 19 UI(a-) mothers with UI(a+) children [1].

In this case report, we describe a woman in whom anti-Ula caused severe HDFN in two pregnancies requiring intrauterine (IU) transfusions.

\section{Case Report}

The patient had a history of a normal first pregnancy, in which antenatal antibody screening was negative, and she delivered a healthy girl with a ceasarean section due to fetopelvic disproportion.

In her second pregnancy three years later, the antenatal antibody screening was also negative. In a follow-up ultrasound examination performed at $27+5$ weeks of gestation 
because of mild pyelectasy, the fetus showed signs of severe anemia: ascites, pericardiac effusion, and a high peak systolic velocity (PSV) in the middle cerebral artery (MCA) were seen. In diagnostic umbilical cord sampling at $28+2$ weeks of gestation, the hemoglobin $(\mathrm{Hb})$ was $2.8 \mathrm{~g} / \mathrm{dL}$ and reticulocytes $44 \%$. Two days later at $28+4$ weeks of gestation, in IU transfusion, the $\mathrm{Hb}$ was $2.6 \mathrm{~g} / \mathrm{dL}$. A second IU transfusion was performed at $31+1$ weeks of gestation. Fetal ascites persisted, the mother was in discomfort because of polyhydramnion, and the diagnosis remained unknown; therefore, the baby girl was delivered at $31+6$ weeks of gestation with a ceasarean section, with a $\mathrm{Hb}$ of $4.3 \mathrm{~g} / \mathrm{dL}$ and a negative direct antiglobulin test (DAT). The newborn was treated with exchange transfusion, RBC transfusion, and platelet transfusion. The bilirubin level was 17 , rising to 72 at two weeks of age when jaundice was also present, and normalized at four weeks of age. Biliary occlusion was suspected. The cause of anemia was unknown, but thought to be non-immune in origin.

In her third pregnancy three years later, the antenatal antibody screening was negative in the beginning of pregnancy, but given her history of an anemic child, antibody detection panel was performed, leading to the detection of
anti-Ula antibody with an initial titer of 1 and a final titer of 2 . The father was found to be $\mathrm{Ul}(\mathrm{a}+)$. In ultrasound examination at $25+1$ weeks of gestation, the fetus was hydroptic, the PSV of the MCA was $>1.5$ multiples of median (MoM), indicating severe anemia. Umbilical cord sampling at $25+5$ weeks of gestation revealed a $\mathrm{Hb}$ of $2.8 \mathrm{~g} / \mathrm{dL}$. In the first IU transfusion performed two days later, the $\mathrm{Hb}$ was $2.3 \mathrm{~g} / \mathrm{dL}$. Altogether six IU transfusions were performed between $26+0$ and $33+6$ weeks of gestation. A baby girl was delivered with a ceasarean section at 35+1 weeks of gestation, with a $\mathrm{Hb}$ of $10.9 \mathrm{~g} / \mathrm{dL}$, a reticulocyte count of $2.3 \%$, a positive DAT, and phenotyped $\mathrm{UI}(\mathrm{a}+)$. After delivery, the anti-Ula titer was 4 . The newborn received $\mathrm{RBC}$ transfusion increasing the $\mathrm{Hb}$ to $11.8 \mathrm{~g} / \mathrm{dL}$. The bilirubin level was initially 129-151, and 134-125 on day 3 . Phototherapy was given 4 times until day 4 . The preterm baby also suffered from mild respiratory problems in the beginning but otherwise recovered well.

Around this time, blood samples were taken from the two older children, aged 6 and 3 years at the time, and they were also phenotyped $\mathrm{UI}(\mathrm{a}+)$. The courses and outcomes of the pregnancies are also presented in Table 1.

Table 1: Courses and outcomes of the pregnancies.

\begin{tabular}{|c|c|c|c|}
\hline & Pregnancy 1 & Pregnancy 2 & Pregnancy 3 \\
\hline Antibody screening & Negative & Negative & Negative \\
\hline Antibody detection & Not done & Not done & Anti-Ula \\
\hline Antibody titer & & & $\begin{array}{l}\text { Prenatal 1-2 } \\
\text { Postnatal } 4\end{array}$ \\
\hline Prenatal follow-up & & MCA PSV weekly from $27+5$ weeks & $\begin{array}{l}\text { Monthly antibody levels; MCA PSV weekly } \\
\text { from } 25+1 \text { weeks }\end{array}$ \\
\hline Intervention & None & $\begin{array}{l}\text { Diagnostic umbilical cord sampling at } 28+2 \\
\text { weeks: } \mathrm{Hb} 2.8 \mathrm{~g} / \mathrm{dL} \\
\text { IUT } \times 2\end{array}$ & $\begin{array}{l}\text { Diagnostic umbilical cord sampling at } 25+5 \\
\text { weeks: } \mathrm{Hb} 2.8 \mathrm{~g} / \mathrm{dL} \\
\text { IUT } \times 6\end{array}$ \\
\hline Delivery & CS at term & CS at $31+6$ weeks & CS at $35+1$ weeks \\
\hline Outcome & Healthy girl & $\begin{array}{l}\text { Girl, } \mathrm{Hb} 4.3 \mathrm{~g} / \mathrm{dL} \text {, } \\
\text { DAT- }\end{array}$ & $\begin{array}{l}\text { Girl, } \mathrm{Hb} 10.9 \mathrm{~g} / \mathrm{dL} \text {, } \\
\text { DAT+ }\end{array}$ \\
\hline Neonatal treatment & Not needed & $\begin{array}{l}\text { Exchange transfusion, } \mathrm{RBC} \text { and platelet } \\
\text { transfusion }\end{array}$ & RBC transfusion, physiotherapy $\times 4$ \\
\hline $\begin{array}{l}\mathrm{MCA}=\text { middle cerebr } \\
\mathrm{CS}=\text { ceasarean secti }\end{array}$ & $\begin{array}{l}\text { k systolic veloc } \\
\mathrm{n} ; \mathrm{DAT}=\text { direct a }\end{array}$ & $\begin{array}{l}\text {; } \mathrm{RBC}=\text { red blood cell }\end{array}$ & \\
\hline
\end{tabular}

\section{Methods and Results}

All blood samples were analyzed at the Finnish Red Cross Blood Service in Helsinki, a national reference laboratory to which all prenatal screening for RBC antibodies is centralized. According to the national protocol for prenatal antibody screening, maternal sampling began at 8-12 weeks of gestation in all pregnancies. The postnatal blood samples were drawn on the day of delivery.

$A B O$ and RhD typing of RBC samples were performed with an automated analyzer (PK7300, Olympus Corporation, Japan) on microtiter plates. Antibody screening, identification, and DAT studies were carried out with a gel-based analyzer (DiaMed ID Gelstation, Diamed, Switzerland). Titrations were performed using the tube method for indirect antiglobulin test and $\mathrm{UI}(\mathrm{a}+)$ reagent RBCs for anti-Ula.

The antibody screening with two cells was negative in all three pregnancies. Antibody identification was performed in the third pregnancy showing an anti-Ula (Kell) antibody.

The mother was phenotyped as $A B ; D+C+C+E+e+K-; U I(a-)$; Fy $(a-b+) ; J k(a-b+) ; S+s+; L W(b-)$ and the father as $A ; D+C+c+E+e$ 
$+\mathrm{K}-; \mathrm{UI}(\mathrm{a}+) ; \mathrm{Jk}(\mathrm{a}+\mathrm{b}+)$. The father was the same in all pregnancies.

In the third pregnancy, the anti-Ula titer was initially 1 , and finally 2. After delivery, the titer was 4 . After the delivery of her third child, phenotyped as A+; $\mathrm{D}+; \mathrm{UI}(\mathrm{a}+)$, blood samples were obtained from the two older children, who were also phenotyped as A+; D+; Ul(a+).

\section{Discussion}

The most important antibodies responsible for severe HDFN are anti-D and anti-c of the Rh blood group system, and anti- $K$ of the Kell system. Others, albeit much less common, include anti-Jka (the Kidd system), anti-Fya (the Duffy system), and the MNS system antibodies [6-8]. The antibody screening cells are positive for these antigens, whereas many rare antigens such as Ula, are not necessarily included and therefore, anti-Ula is hard to detect. However, it is not generally considered to cause severe HDFN. When the antibody screening result is negative, a full antibody detection panel will not be performed unless there is a history of previous antibodies.

This was the case with our patient, who had been sensitized to Ula in her first pregnancy, and immunization manifested in the following ones. She underwent only the normal antibody screening protocol in her first two pregnancies and no further antibody studies were conducted. Therefore, when the fetus was found anemic in the second pregnancy, the cause was suspected to be other than RBC immunization. In her third pregnancy, the antibody screening was again negative, but given the mother's history, this time a full antibody detection panel was performed, and anti-Ula identified. After the last delivery, all her children were found to be $\mathrm{Ul}(\mathrm{a}+)$, which explained the anemia in the second child.

Ula, also named KEL10, is part of the Kell blood group system, wherein the most important antibody is anti-K; only anti-D is more immunogenic [9]. The mechanism by which anti-K causes RBC hemolysis differs from the Rh and $A B O$ system antibodies; the Kell blood group antigens are expressed on the surface of RBC precursors and anti- $K$ promotes the destruction of these RBC progenitor cells before $\mathrm{Hb}$ production, thus causing anemia to develop in an insidious manner. Due to residual anti-K, the infant may also suffer from reticulocytopenia caused by continual suppression of erythropoiesis. Therefore, neither anti- $K$ titer levels nor the measurement of bilirubin, an $\mathrm{Hb}$ breakdown product in amniotic fluid, are reliable in predicting the severity of HDFN $[9,10]$. Ultrasound examinations to detect signs of fetal anemia should begin already at low titer levels, and include Doppler measurement of the PSV of the MCA and evaluation of signs of fetal hydrops; even a titer as low as 2 has been associated with severe HDFN [11]. In anemic fetuses, lower blood viscosity and increased cardiac output result in a higher PSV with a threshold value of $1.5 \mathrm{MoM}$ predicting moderate to severe anemia [6,12]. As members of the same antigen family, antiUla and anti-K can be assumed to cause HDFN via similar mechanisms.
Anti-Ula is rare due to the very low occurrence of the Ula antigen $[1,3,13]$. To our knowledge, only one case of anti-Ula as the cause of HDFN has been reported previously [5]. In our case, the mother was a high responder to this antigen and developed anti-Ula resulting in two cases of severe HDFN. In general, the ability to produce antibodies against a given antigen and the magnitude of the immune response, vary among individuals. Factors affecting the development of an antibody may depend on the number of occasions the person is exposed to the lacking antigen, the amount of such RBC received, the immunogenicity of the antigen, and perhaps genetic factors [14]

In conclusion, anti-Ula is a rare antibody, but capable of causing severe HDFN even at low titer levels. In cases of unknown fetal or newborn anemia, antibody detection panels can be useful in search for uncommon antibodies, even if the antibody screening has been negative. Close collaboration between the immunohematology laboratory and the obstetric unit is essential.

\section{Competing Interests}

The authors declare that they have no competing interests.

\section{References}

1. Furuhjelm U, Nevanlinna HR, Nurkka R, Gavin J, Tippett $P$, et al. (1968) The blood group antigen Ula (Karhula). Vox Sang 15: 118-124.

2. Furuhjelm U, Nevanlinna HR, Nurkka R, Gavin J, Sanger R (1969) Evidence that the antigen Ula is controlled from the Kell complex locus. Vox Sang 16: 496-499.

3. Reid M, Lomas-Francis C, Olsson ML (2012) The blood group antigen facts book (3rdedn) Elsevier.

4. Daniels G (2013) Human Blood Groups (3rdedn) Wiley Blackwell.

5. Sakuma K, Suzuki H, Ohto H, Tsuneyama H, Uchikawa M (1994) First case of hemolytic disease of the newborn due to anti-Ula antibodies. Vox Sang 66: 293-294.

6. Eder AF (2008) Update on HDFN: new information on longstanding controversies. Immunohematology 22: 188-195.

7. Fasano RM (2016) Hemolytic disease of the fetus and newborn in the molecular era. Semin Fetal Neonatal Med 21: 28-34.

8. Koelewijn JM, Vrijkotte TGM, van der Schoot CE, Bonsel GJ, de Haas M (2008) Screening for red cell antibodies, other than anti$D$, to detect hemolytic disease of the fetus and newborn: a population study in the Netherlands. Transfusion 48: 941-952.

9. Denomme GA (2015) Kell and Kx blood group systems. Immunohematology 31: 14-19.

10. Daniels G, Bromilow I (2014) Essential Guide to Blood Groups (3rdedn) Wiley Blackwell.

11. Moise KJ (2008) Fetal anemia due to non-Rhesus red-cell alloimmunization. Semin Fetal Neonatal Med 13: 207-214.

12. Geaghan SM (2011) Diagnostic laboratory technologies for the fetus and neonate with isoimmunization. Semin Perinatol 35: 148-154. 
13. Okubo $Y$, Yamaguchi $H$, Seno $T$, Miyata $Y$, Moulds $M K$, et al. (1986) The first example of anti-Ula and $\mathrm{UI}(\mathrm{a}+$ ) red cells found in Japan. Transfusion 26: 215.
14. Körmöczi GF, Mayr WR (2014) Responder individuality in red blood cell alloimmunization. Transfus Med Hemother 41: 446-451. 